\title{
Carbon fraction of Pinus radiata biomass components within New Zealand
}

\author{
Peter N. Beets ${ }^{*}$ (D) and Loretta G. Garrett
}

\begin{abstract}
Background: Carbon fractions are applied to dry matter estimates to calculate carbon stocks in forest stands. A default carbon fraction has been applied to planted forest species in New Zealand; however, various studies have shown that the carbon fraction can differ among species and between tree components. New Zealand-specific carbon fractions were, therefore, developed to improve the accuracy of carbon stock estimates for international reporting purposes.

Methods: Carbon fractions were analysed using subsamples of tree components from 684 stems, 1125 crowns and 70 root systems from 14 sites distributed throughout New Zealand. The carbon fractions for needles, branches, cones, stem wood, stem bark and roots reported by the laboratory at a drying temperature of $104^{\circ} \mathrm{C}$ were corrected using published procedures to the moisture content attained after drying subsamples to constant weight at $70^{\circ} \mathrm{C}$, the drying temperature used in New Zealand biomass studies.

Results: Carbon fraction averaged $0.514 \mathrm{~g} \mathrm{C} \mathrm{g}^{-1} \mathrm{dm}$ in needles, $0.507 \mathrm{~g} \mathrm{C} \mathrm{g}^{-1} \mathrm{dm}$ in branches, $0.519 \mathrm{~g} \mathrm{C} \mathrm{g}^{-1} \mathrm{dm}$ in cones, $0.498 \mathrm{~g} \mathrm{C} \mathrm{g}^{-1} \mathrm{dm}$ in stem wood, $0.501 \mathrm{~g} \mathrm{C} \mathrm{g}^{-1} \mathrm{dm}$ in roots, and $0.539 \mathrm{~g} \mathrm{C} \mathrm{g}^{-1} \mathrm{dm}$ in stem bark of radiata pine. The stem bark carbon fraction increased asymptotically with stand age.

Conclusions: The default carbon fraction $\left(0.50 \mathrm{~g} \mathrm{C} \mathrm{g}^{-1} \mathrm{dm}\right)$ used previously in the FCP model underestimates carbon stocks in New Zealand's planted forest estate. Applying carbon fractions derived from New Zealand biomass studies will increase carbon stock estimates for the planted forest land by approximately $1 \%$ and also increase estimates of removals during harvesting operations. Information on in-forest debarking activities will further improve estimates of removals associated with harvesting.
\end{abstract}

Keywords: Biomass, Carbon stocks, Carbon fraction, Douglas-fir, Radiata pine

\section{Introduction}

The net stocked area of planted forest in New Zealand covered approximately 1.7 million ha as of 1 April 2016, which was comprised of Pinus radiata, D.Don (radiata pine 90\%), Pseudotsuga menziesii (Mirb.) Franco (Douglas-fir 6\%) and a range of minor species including eucalypts and cypress (NEFD 2016). Unbiased estimates of carbon (C) stocks and changes in New Zealand's planted and natural forests are required to meet international reporting commitments under the United Nations Framework Convention on Climate Change (UNFCCC) and the Kyoto Protocol. The national inventory of planted forest provides data for developing carbon yield tables, which are derived from a modelling system

\footnotetext{
* Correspondence: peter.beets@scionresearch.com
}

Scion, Private Bag 3020, Rotorua 3046, New Zealand called the Forest Carbon Predictor (FCP) (Beets et al. 2011). The FCP estimates the dry matter content of live tree components, which is converted to carbon by applying a carbon fraction. The amount of carbon (i.e. the carbon fraction) in biomass components is currently assumed to be $0.50 \mathrm{~g} \mathrm{C}$ per gram of dry matter $\left(\mathrm{g}^{-1} \mathrm{dm}\right)$, which differs slightly from default fraction in the IPCC guidelines (IPCC 2006), which is 0.51 in temperate and boreal conifers. Given the importance of planted forests as a carbon sink in New Zealand, it is important to develop New Zealand-specific carbon fractions.

The amount of carbon contained in the dry matter component containing needles, branches, stem wood, stem bark and roots has been examined in a number of coniferous species (Balboa-Murias et al. 2006; Bert and Danjon 2006; De Aza et al. 2011) and is reported to vary 
between species and among biomass components, as was highlighted in a recent review (Thomas and Martin 2012). For carbon estimation purposes, biomass samples need to account for within- and between-tree variation in carbon content to provide unbiased estimates of the carbon fraction. For example, a composite sample of mass-weighted stem wood or bark subsamples taken at fixed intervals along the entire length of stems will provide representative material, while for needles and branches, mass-weighted subsamples from throughout the crown will provide representative material for chemical analysis. Tree biomass sampling procedures are specifically designed to provide representative samples of individual biomass components, thus providing suitable subsamples for carbon analysis. A weighted average carbon fraction has been derived for various species (Thomas and Martin 2012); however, the application of a single carbon fraction for a species implies that partitioning of components is fixed. This is not the case in New Zealand's intensively managed planted forests, where the disposition of components varies with site, stand age and the silvicultural regime (Madwick et al. 1977; Beets and Pollock 1987; Beets and Madgwick 1988). An alternative approach is to apply carbon fractions to each biomass component separately. Component-specific carbon fractions can be implemented within the FCP as it provides annual estimates of the dry matter content of needles by age class, live branches, dead branches, cones, stem wood, stem bark and roots from time of planting to harvesting.

To improve the accuracy of carbon stock estimates for planted forests in New Zealand, carbon data from radiata pine biomass studies across a range of sites and ages were summarised by component and stand age, so as to incorporate suitable carbon fractions within the Forest Carbon Predictor. In this paper, component-specific carbon fractions were tabulated for radiata pine along with limited data for Douglas-fir grown in New Zealand, Also, an assessment of the impact of the revised fractions on biomass carbon stock estimates is provided.

\section{Methods}

Oven-dried $\left(70^{\circ} \mathrm{C}\right)$ stem wood, stem bark, branch, cone and needle samples for carbon analysis were obtained from existing and new radiata pine and Douglas-fir biomass studies in New Zealand. Dead needles intercepted by branches in the lower crown were collected separately from live needles. Biomass studies in radiata pine stands were undertaken in 5- and 15-year-old stands at Kinleith, 5-, 16- and 26-year-old stands at Tarawera, 5and 28-year-old stands at Woodhill and a 5-year-old stand at Nelson. Carbon data from the 15- and 16-year-old stands at Kinleith and Tarawera, respectively, were published by Oliver et al. (2011). Biomass samples were also acquired at eight Genotype $\times$ Environment $(G \times E)$ trial sites established in the North and South Island of New Zealand, each planted with 40 clonally propagated genotypes. At these sites, stem wood, stem bark, and needle biomass samples were obtained from 96 trees (one tree from each of the 12 genotypes per site) in 2017 in 12- to 15-year-old stands. In addition, branch and root samples (10 to $\leq 50 \mathrm{~mm}$ diameter over bark) were acquired from recently harvested stands at nine sites located within New Zealand commercial plantations as part of woody debris decay studies (Garrett et al. 2008, 2010, 2012). Finally, outer bark (cork) from disc samples taken at fixed intervals along the entire stem length of 19 trees (stands aged $22 / 23$ years old) at Puruki Forest was separated from inner bark (phloem and phelloderm) using a chisel, which was only feasible from discs in the lower part of the stem. This corky bark was bulked into a single sample per tree and labelled "outer bark". The inner bark and bark from upper discs that could not be separated from the inner bark was bulked by tree and labelled "inner bark". One 10-year-old Douglas-fir stand was sampled at Gowan Hill, Southland, which provided needle, branch and stem wood and bark samples for comparison purposes. The oven-dried $\left(70^{\circ} \mathrm{C}\right)$ samples were processed as follows.

Woody biomass samples were chipped and then ground until all the material passed through a 2-mm mesh sieve, while needle samples were ground until all the material passed through a 1-mm mesh sieve. Because the samples had been exposed to air for an indefinite period of time, they had gained moisture. Carbon $(\mathrm{C})$ content of these samples was determined by thermal combustion (Leco CNS-2000, LECO Corp., St Joseph, MI, USA). Carbon fractions (CFs) reported by the laboratory were based on moisture factors of subsamples dried for $24 \mathrm{~h}$ at a drying temperature of $104{ }^{\circ} \mathrm{C}$. The moisture factors (s.e.) averaged 1.087 (0.0008) for stem wood, $1.096(0.0008)$ for stem bark and 1.077 (0.0008) for needles. These moisture factors provide carbon fractions at a drying temperature of $104{ }^{\circ} \mathrm{C}$ and were, therefore, back-corrected to the moisture content of biomass samples oven dried to constant weight at $70^{\circ}$ $\mathrm{C}$, the drying temperature used in New Zealand biomass studies. Carbon fractions were back-corrected as follows: $\mathrm{CF}_{70}=\mathrm{CF}_{104} \times(100-1.045) / 100$ (following Bert and Danjon 2006), where $\mathrm{CF}_{70}$ is the carbon fraction applied to biomass data, $\mathrm{CF}_{104}$ is the carbon fraction reported by the laboratory and 1.045 is the percentage reduction in moisture content of biomass samples oven dried to constant weight at $70{ }^{\circ} \mathrm{C}$ and then re-dried to constant weight at $104{ }^{\circ} \mathrm{C}$.

For radiata pine, data for each component were examined for variation with tree age. The carbon fraction in 
stem bark was the only component to vary significantly as a function of stand age. The carbon fraction in stem bark was modelled as a function of age using the NLIN procedure (Gaus-Newton method) in SAS Version 9.4 statistical analysis software (SAS Institute Inc. 2011). For components other than stem bark, the overall mean across sites was calculated by component.

The impact of replacing the default carbon fraction $\left(0.50 \mathrm{~g} \mathrm{C}^{-1} \mathrm{dm}\right)$ by the revised carbon fractions was assessed by applying carbon fractions to stem wood, stem bark, needle, branch and cone dry matter estimates from a radiata pine chronosequence study (Madwick et al. 1977; Webber and Madgwick 1983).

\section{Results}

Carbon fractions of radiata pine tree components

The carbon fractions of radiata pine tree components are summarised in Table 1. The mean carbon fraction across sites averaged (standard error in parenthesis) $0.498 \mathrm{~g} \mathrm{C} \mathrm{g}^{-1} \mathrm{dm}$ (0.001) for stem wood, $0.501 \mathrm{~g} \mathrm{C} \mathrm{g}^{-1} \mathrm{dm}$ (0.004) for coarse roots, $0.514 \mathrm{~g} \mathrm{C} \mathrm{g}^{-1} \mathrm{dm}$ (0.002) for live needles, 0.507 $\mathrm{g} \mathrm{C} \mathrm{g}^{-1} \mathrm{dm}(0.002)$ for branches and $0.519 \mathrm{~g} \mathrm{C} \mathrm{g}^{-1} \mathrm{dm}(0.004)$ for cones. Dead fallen needles from upper branches intercepted by branches in the lower crown averaged $0.514 \mathrm{~g} \mathrm{C} \mathrm{g}^{-1} \mathrm{dm}$ (data not shown), which was the same as the value obtained for live needles. For stem bark, the overall mean carbon fraction averaged $0.539 \mathrm{~g} \mathrm{C} \mathrm{g}^{-1} \mathrm{dm}$

Table 1 Mean carbon fraction of radiata pine biomass components, age of sample stand, number of stems/crowns/roots sampled (n) and study sites in New Zealand

\begin{tabular}{|c|c|c|c|c|c|c|c|c|}
\hline \multirow[t]{2}{*}{ Site } & \multirow[t]{2}{*}{$\begin{array}{l}\text { Stand age } \\
\text { (years) }\end{array}$} & \multirow[t]{2}{*}{$\begin{array}{l}n \text { (stem/crown/ } \\
\text { root) }\end{array}$} & \multicolumn{6}{|c|}{$\begin{array}{l}\text { Carbon fraction ( } \pm \text { se) } \\
\left(\mathrm{g} C \mathrm{~g}^{-1} \mathrm{dm}\right)\end{array}$} \\
\hline & & & Stem wood & Stem bark & Branches & Needles & Cones & Roots $^{2}$ \\
\hline Balmoral, SI & 28 & $0 / 3 / 6$ & $\mathrm{n} / \mathrm{a}$ & $\mathrm{n} / \mathrm{a}$ & 0.510 & $\mathrm{n} / \mathrm{a}$ & $\mathrm{n} / \mathrm{a}$ & 0.506 \\
\hline Burnham, SI & 28 & $0 / 4 / 8$ & $\mathrm{n} / \mathrm{a}$ & $\mathrm{n} / \mathrm{a}$ & 0.521 & $\mathrm{n} / \mathrm{a}$ & $\mathrm{n} / \mathrm{a}$ & 0.510 \\
\hline Crater Block, NI & 13 & $12 / 12 / 0$ & 0.497 & 0.546 & $\mathrm{n} / \mathrm{a}$ & 0.526 & $\mathrm{n} / \mathrm{a}$ & $\mathrm{n} / \mathrm{a}$ \\
\hline Forest Creek, SI & 14 & $12 / 12 / 0$ & 0.500 & 0.549 & $\mathrm{n} / \mathrm{a}$ & 0.515 & $\mathrm{n} / \mathrm{a}$ & $\mathrm{n} / \mathrm{a}$ \\
\hline \multirow[t]{2}{*}{ Golden Downs, SI } & 5 & $120 / 240 / 0$ & 0.500 & 0.508 & 0.515 & 0.507 & $\mathrm{n} / \mathrm{a}$ & $\mathrm{n} / \mathrm{a}$ \\
\hline & 28 & $0 / 2 / 4$ & $\mathrm{n} / \mathrm{a}$ & $\mathrm{n} / \mathrm{a}$ & 0.495 & $\mathrm{n} / \mathrm{a}$ & $\mathrm{n} / \mathrm{a}$ & 0.509 \\
\hline \multirow[t]{2}{*}{ Kaingaroa, $\mathrm{NI}$} & 12 & $12 / 12 / 0$ & 0.497 & 0.545 & $\mathrm{n} / \mathrm{a}$ & 0.509 & $\mathrm{n} / \mathrm{a}$ & $\mathrm{n} / \mathrm{a}$ \\
\hline & 28 & $0 / 2 / 4$ & $\mathrm{n} / \mathrm{a}$ & $\mathrm{n} / \mathrm{a}$ & 0.493 & $\mathrm{n} / \mathrm{a}$ & $\mathrm{n} / \mathrm{a}$ & 0.494 \\
\hline \multirow[t]{3}{*}{ Kinleith, NI } & 5 & $120 / 240 / 0$ & 0.499 & 0.518 & 0.507 & 0.501 & $\mathrm{n} / \mathrm{a}$ & $\mathrm{n} / \mathrm{a}$ \\
\hline & 10 & 0/0/9 & $\mathrm{n} / \mathrm{a}$ & $\mathrm{n} / \mathrm{a}$ & $\mathrm{n} / \mathrm{a}$ & $\mathrm{n} / \mathrm{a}$ & $\mathrm{n} / \mathrm{a}$ & 0.498 \\
\hline & 15 & $24 / 47 / 3$ & 0.504 & 0.539 & 0.515 & 0.508 & 0.520 & 0.478 \\
\hline Lawrence, SI & 14 & $12 / 12 / 0$ & 0.496 & 0.557 & $\mathrm{n} / \mathrm{a}$ & 0.514 & $\mathrm{n} / \mathrm{a}$ & $\mathrm{n} / \mathrm{a}$ \\
\hline Lochinver, NI & 14 & $12 / 12 / 0$ & 0.494 & 0.550 & $\mathrm{n} / \mathrm{a}$ & 0.517 & $\mathrm{n} / \mathrm{a}$ & $\mathrm{n} / \mathrm{a}$ \\
\hline Mahia, NI & 15 & $12 / 12 / 0$ & 0.498 & 0.556 & $\mathrm{n} / \mathrm{a}$ & 0.520 & $\mathrm{n} / \mathrm{a}$ & $\mathrm{n} / \mathrm{a}$ \\
\hline \multirow[t]{2}{*}{ Rotoehu, NI } & 12 & $12 / 12 / 0$ & 0.496 & 0.545 & $\mathrm{n} / \mathrm{a}$ & 0.517 & $\mathrm{n} / \mathrm{a}$ & $\mathrm{n} / \mathrm{a}$ \\
\hline & 28 & $0 / 1 / 6$ & $\mathrm{n} / \mathrm{a}$ & $\mathrm{n} / \mathrm{a}$ & 0.499 & $\mathrm{n} / \mathrm{a}$ & $\mathrm{n} / \mathrm{a}$ & 0.493 \\
\hline \multirow[t]{5}{*}{ Tarawera, NI } & 5 & $120 / 270 / 8$ & 0.494 & 0.510 & 0.510 & 0.510 & $\mathrm{n} / \mathrm{a}$ & 0.510 \\
\hline & 11 & $0 / 0 / 4$ & $\mathrm{n} / \mathrm{a}$ & $\mathrm{n} / \mathrm{a}$ & $\mathrm{n} / \mathrm{a}$ & $\mathrm{n} / \mathrm{a}$ & $\mathrm{n} / \mathrm{a}$ & 0.532 \\
\hline & 16 & $24 / 48 / 4$ & 0.509 & 0.545 & 0.514 & 0.523 & 0.525 & 0.491 \\
\hline & 26 & $24 / 48 / 0$ & 0.498 & 0.546 & 0.509 & 0.514 & 0.511 & $\mathrm{n} / \mathrm{a}$ \\
\hline & 28 & $0 / 2 / 4$ & $\mathrm{n} / \mathrm{a}$ & $\mathrm{n} / \mathrm{a}$ & 0.501 & $\mathrm{n} / \mathrm{a}$ & $\mathrm{n} / \mathrm{a}$ & 0.498 \\
\hline West Coast, SI & 28 & $0 / 1 / 6$ & $\mathrm{n} / \mathrm{a}$ & $\mathrm{n} / \mathrm{a}$ & 0.504 & $\mathrm{n} / \mathrm{a}$ & $\mathrm{n} / \mathrm{a}$ & 0.503 \\
\hline \multirow[t]{3}{*}{ Woodhill, NI } & 5 & $120 / 120 / 0$ & 0.495 & 0.509 & 0.507 & 0.514 & $\mathrm{n} / \mathrm{a}$ & $\mathrm{n} / \mathrm{a}$ \\
\hline & 13 & $12 / 12 / 0$ & 0.493 & 0.539 & $\mathrm{n} / \mathrm{a}$ & 0.510 & $\mathrm{n} / \mathrm{a}$ & $\mathrm{n} / \mathrm{a}$ \\
\hline & 28 & $36 / 1 / 4$ & 0.498 & 0.554 & 0.503 & $\mathrm{n} / \mathrm{a}$ & $\mathrm{n} / \mathrm{a}$ & 0.497 \\
\hline Mean & & & 0.498 & 0.539 & 0.507 & 0.514 & 0.519 & 0.501 \\
\hline \pm se & & & 0.001 & 0.004 & 0.002 & 0.002 & 0.004 & 0.004 \\
\hline
\end{tabular}

Carbon is expressed per unit dry matter $(\mathrm{dm})$ oven dried at $70{ }^{\circ} \mathrm{C}$ Live needles

${ }^{1} 10 \mathrm{~mm}$ to $\leq 50 \mathrm{~mm}$ diameter over bark 
(0.004); however, the mean carbon fraction increased with age from $0.508 \mathrm{~g} \mathrm{C} \mathrm{g}^{-1} \mathrm{dm}$ at age 5 to $0.554 \mathrm{~g} \mathrm{C} \mathrm{g}^{-1} \mathrm{dm}$ at stand age 28 years (Fig. 1). No significant trends with age were evident for other components.

Means and ranges in component carbon fractions averaged across the eight $\mathrm{G} \times \mathrm{E}$ trial sites, and 12 genotypes are summarised in Table 2. Carbon fractions differed significantly between sites and among clones, although the differences are relatively small and impractical to implement (Table 2).

The carbon fraction in stem bark of New Zealand-grown radiata pine follows an asymptotic relationship with age (Fig. 1) given by:

$$
\mathrm{CF}_{\text {stembark }}=0.551 \times(1-0.291 \times \exp (-0.280 \times \text { Age }))
$$

The model was fitted to a total of 16 stands from 5 to 28 years old at 11 sites, three of which (Woodhill, Kinleith, Tarawera) were sampled at multiple ages (Table 1). The model has an $R^{2}=0.91$ and root mean square error $=0.057$. Stem bark was the only tree component where the carbon fraction varied significantly with stand age. The asymptote was reached by around stand age 12 years.

\section{Carbon fraction of radiata pine bark components}

The carbon fraction of the inner and outer bark of 22/ 23-year-old trees at Puruki Forest is summarised in Table 3. The carbon fraction of the outer bark exceeded that of the inner bark by approximately $14 \%$. The bark of very young trees is equivalent to the inner bark, while the outer bark becomes evident as trees increase in age. The results for the inner and outer bark are consistent with the finding that the carbon fraction of bark initially increases with age, until the bark layer becomes dominated by cork.

\section{Carbon fraction of Douglas-fir components}

The mean and range in carbon fraction $\left(\mathrm{g} \mathrm{C} \mathrm{g}^{-1} \mathrm{dm}\right)$ of biomass components for one Douglas-fir stand in New Zealand are summarised in Table 4. The mean carbon fraction was lowest in stem wood $\left(0.502 \mathrm{~g} \mathrm{C} \mathrm{g}^{-1} \mathrm{dm}\right)$, intermediate in needles and branches and highest in stem bark $\left(0.534 \mathrm{~g} \mathrm{C} \mathrm{g}^{-1} \mathrm{dm}\right)$. These results for Douglas-fir are very similar to those reported above for New Zealand-grown radiata pine.

\section{Discussion}

Various studies of conifers growing in countries other than New Zealand show that carbon fractions can differ appreciably among species and tree components (Table 5). The New Zealand-grown radiata pine carbon fractions reported here are based on wood and bark samples from 684 stems, 1125 crowns and 70 root systems from a total of 14 sites distributed throughout New Zealand. The samples were obtained from biomassspecific studies and are considered representative of each tree component. These data show similar trends to radiata pine in Spain (Table 5), with the $C$ fraction in the stem bark being the highest, needles and branches intermediate and stem wood lowest. For most species, heartwood has a higher carbon fraction than sapwood, and branches, roots and needles tend to be intermediate between stem sapwood and stem bark (Table 5). Explanations offered for differences in carbon fractions are summarised in reviews by Matthews (1993), Bert and Danjon (2006) and Thomas and Martin (2012). Species

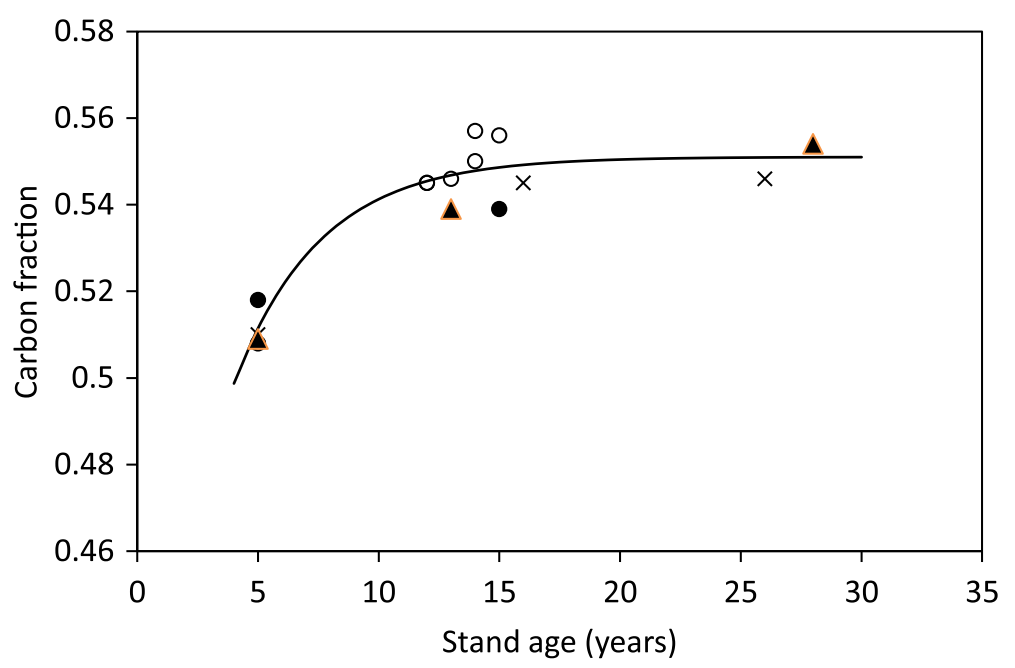

Fig. 1 Carbon fraction of stem bark as a function of stand age in New Zealand radiata pine biomass studies. Three sites were sampled at multiple ages: Woodhill (triangles), Kinleith (dots) and Tarawera (crosses). The remaining eight sites were sampled only at one age (circles). The line shows the fitted exponential function: $\mathrm{CF}_{\text {stembark }}=0.551 \times(1-0.291 \times \exp (-0.280 \times$ Age $))$ 
Table 2 Carbon fraction-summary of $G \times E$ trials sampled at approximately mid-rotation ages

\begin{tabular}{lllllll}
\hline Component & Mean & Site & & & Genotype \\
& & Min & Max & & Min & Max \\
\hline Stem wood & 0.496 & 0.493 & 0.500 & & 0.494 & 0.500 \\
Stem bark & 0.548 & 0.538 & 0.557 & & 0.538 & 0.564 \\
Needles & 0.516 & 0.509 & 0.526 & & 0.512 & 0.520 \\
\hline
\end{tabular}

Carbon is expressed per unit dry matter $(\mathrm{dm})$ oven dried at $70^{\circ} \mathrm{C}$

and component-related differences in carbon fractions reflect the relative proportions of high versus low carbon fraction compounds in tissues during, for example, heartwood formation and cell suberisation in bark. The carbon content of cellulose (44.4\%), lignin (66.7\%) and hemi-celluloses (44.4-45.5\%) are reasonably well established (Matthews 1993). Radiata pine has produced very little heartwood by age $20-28$ years, the ages at which it is typically harvested in New Zealand, and the carbon fraction of stem wood varies little with tree age. Radiata pine stem wood was previously estimated to be comprised of lignin $26 \%$, cellulose $42 \%$, galactoglucomannan $15 \%$, arabinoglucuronoxylan $10 \%$, arabinogalactan $4 \%$, utonic acids, etc. 3\% (Uprichard and Lloyd 1980), which gives a moisture-free $C$ fraction of 0.504 , based on methods in Matthews (1993). This value compares favourably to the value of $0.498 \mathrm{~g} \mathrm{C} \mathrm{g}^{-1} \mathrm{dm}$ (Table 1) obtained directly from the measured stem wood carbon fraction in the current study.

The carbon fraction in radiata pine stem bark increased with tree age in New Zealand biomass studies. Other studies have shown that the carbon fraction of stem bark is generally highest at the base of the stem where the proportion of mature bark is greatest (De Aza et al. 2011). More particularly, it has been shown that the outer bark has a higher carbon fraction than inner bark, which was ascribed to higher levels of extractives, lignin, tannins and suberin (Bert and Danjon 2006). The outer bark has a significantly higher carbon fraction than the inner bark in the current study which was based on 19 radiata pine stems, presumably owing to the higher content of lignin and suberin in the outer bark. The proportion of the outer bark in the lower part of the stem increases with tree age, which explains why the stem

Table 3 Carbon fraction summary of inner and outer stem bark in 22/23-year-old radiata pine trees at Puruki Forest

\begin{tabular}{lllll}
\hline Component & \multicolumn{4}{l}{ Carbon fraction } \\
\cline { 3 - 5 } & $n$ & Mean & Minimum & Maximum \\
\hline Stem bark-inner & 19 & 0.503 & 0.472 & 0.558 \\
Stem bark_outer & 19 & 0.575 & 0.549 & 0.628 \\
\hline
\end{tabular}

Carbon is expressed per unit dry matter $(\mathrm{dm})$ oven dried at $70^{\circ} \mathrm{C}$
Table 4 Carbon fractions of Douglas-fir biomass components of eight trees from a 10-year-old stand at Southland

\begin{tabular}{|c|c|c|c|}
\hline \multirow[t]{2}{*}{$\begin{array}{l}\text { Biomass } \\
\text { component }\end{array}$} & \multicolumn{3}{|c|}{$\begin{array}{l}\text { Carbon fraction ( } \pm \text { se) } \\
\left(\mathrm{g} C \mathrm{~g}^{-1} \mathrm{dm}\right)\end{array}$} \\
\hline & Mean & Minimum & Maximum \\
\hline Needles & $0.518(0.003)$ & 0.506 & 0.530 \\
\hline Live branches & $0.513(0.003)$ & 0.503 & 0.523 \\
\hline Dead branches & $0.521(0.003)$ & 0.508 & 0.529 \\
\hline Stem wood & $0.502(0.001)$ & 0.496 & 0.506 \\
\hline Stem bark & $0.534(0.003)$ & 0.520 & 0.543 \\
\hline
\end{tabular}

Carbon is expressed per unit dry matter $(\mathrm{dm})$ at $70^{\circ} \mathrm{C}$

bark carbon fraction increases with tree age in New Zealand radiata pine studies.

The dry mass of biomass samples and hence the carbon content depend on the drying temperature and humidity of the drying oven (Matthews 2010). To minimise bias, carbon fractions reported by laboratories need to be corrected to the moisture content of oven-dry biomass samples. In most studies, biomass samples are oven dried in forced ventilation ovens at $65-75^{\circ} \mathrm{C}$ to constant weight or after a defined period of time in the oven. To minimise carbon and nitrogen volatilisation losses that occur at high temperatures (Samuelsson et al. 2006), comparatively low drying temperatures are used when drying biomass samples to constant weight, which can take up to several weeks for large samples. Losi et al. (2003), for example, noted that charring occurred when attempting to dry biomass samples to constant weight at a temperature of $105^{\circ} \mathrm{C}$. Results of chemical analysis conducted by laboratories are based on very small samples which are dried quickly at comparatively high drying temperatures. For this study, the approach used by Bert and Danjon (2006) to correct the carbon data reported by various laboratories was followed. They noted that the moisture factor applied in the analytical laboratory was based on subsamples dried at $103{ }^{\circ} \mathrm{C}$, whereas the biomass samples had been dried to constant weight at $65^{\circ} \mathrm{C}$, which resulted in a moisture content about $2 \%$ lower than that in their biomass samples. Matthews (2010) found approximately $2.5 \%$ of additional moisture in pine samples dried at $65^{\circ} \mathrm{C}$ compared to when samples were dried at $103^{\circ} \mathrm{C}$ in an air-conditioned laboratory at $20^{\circ} \mathrm{C}$ and $40 \%$ relative humidity. Likewise, the moisture factor of the bulked radiata pine biomass samples in the current study was 1.01045 . These samples had been dried to constant weight at $70{ }^{\circ} \mathrm{C}$ and then further dried to constant weight at $104{ }^{\circ} \mathrm{C}$.

Based on the data obtained here, the values for carbon fractions applied in the FCP should be $0.514 \mathrm{~g} \mathrm{C} \mathrm{g}^{-1} \mathrm{dm}$ for needles, $0.507 \mathrm{~g} \mathrm{C} \mathrm{g} \mathrm{g}^{-1} \mathrm{dm}$ for branches, $0.519 \mathrm{~g} \mathrm{C} \mathrm{g}^{-1} \mathrm{dm}$ for cones, $0.498 \mathrm{~g} \mathrm{C} \mathrm{g}^{-1} \mathrm{dm}$ for stem wood and $0.501 \mathrm{~g} \mathrm{C} \mathrm{g}^{-1} \mathrm{dm}$ for roots. For stem bark, the carbon fraction (the mean 
Table 5 Component carbon fraction, number of sample trees per stand ( $n$ ), country of study and source of data for various Pinus

\begin{tabular}{|c|c|c|c|c|c|c|c|}
\hline Species & Component & Age (years) & Number & $\begin{array}{l}\text { Carbon Fraction } \\
\left(\mathrm{g} C \mathrm{~g}^{-1} \mathrm{dm}\right)\end{array}$ & $\begin{array}{l}\text { Biomass } \\
\text { samples } \\
\text { dried }\left({ }^{\circ} \mathrm{C}\right)\end{array}$ & Country & Source \\
\hline \multirow[t]{2}{*}{ P. nigra } & Stem sapwood & $27-39$ & 112 & 0.465 & 75 & Spain & De Aza et al. 2011 \\
\hline & Stem bark & & 106 & 0.499 & & & \\
\hline \multirow[t]{3}{*}{ P. pinaster } & Stem heartwood & $29-50$ & 87 & 0.495 & & & \\
\hline & Stem sapwood & & 156 & 0.458 & & & \\
\hline & Stem bark & & 137 & 0.501 & & & \\
\hline \multirow[t]{3}{*}{ P. sylvestris } & Stem heartwood & $36-53$ & 76 & 0.523 & & & \\
\hline & Stem sapwood & & 166 & 0.453 & & & \\
\hline & Stem bark & & 166 & 0.485 & & & \\
\hline \multirow[t]{6}{*}{ P. radiata } & Stem wood & Unknown & 54 & 0.504 & 65 & Spain & Balboa-Murias et al. 2006 \\
\hline & Stem bark & & 54 & 0.541 & & & \\
\hline & Large branches & & 54 & 0.513 & & & \\
\hline & Small branches & & 54 & 0.525 & & & \\
\hline & Twigs & & 54 & 0.532 & & & \\
\hline & Needles & & 54 & 0.527 & & & \\
\hline \multirow[t]{6}{*}{ P. pinaster } & Stem wood & & 125 & 0.471 & & & \\
\hline & Stem bark & Unknown & 125 & 0.508 & & & \\
\hline & Large branches & & 125 & 0.479 & & & \\
\hline & Small branches & & 125 & 0.505 & & & \\
\hline & Twigs & & 125 & 0.497 & & & \\
\hline & Needles & & 125 & 0.497 & & & \\
\hline \multirow[t]{13}{*}{ P. pinaster } & Stem heartwood & 50 & 4 & 0.544 & 65 & France & Bert and Danjon 2006 \\
\hline & Stem sapwood & & 4 & 0.523 & & & \\
\hline & Stem inner bark & & 4 & 0.510 & & & \\
\hline & Stem outer bark & & 4 & 0.559 & & & \\
\hline & Dead branch & & 4 & 0.534 & & & \\
\hline & Live branch & & 4 & 0.535 & & & \\
\hline & Cones & & 4 & 0.534 & & & \\
\hline & Needles & & 4 & 0.536 & & & \\
\hline & Taproot wood & & 4 & 0.517 & & & \\
\hline & Taproot bark & & 4 & 0.549 & & & \\
\hline & Coarse root wood & & 4 & 0.513 & & & \\
\hline & Coarse root bark & & 4 & 0.544 & & & \\
\hline & Tree total & & & 0.532 & & & \\
\hline
\end{tabular}

Bert and Danjon (2006) reported carbon fractions (the analytical laboratory used $103^{\circ} \mathrm{C}$ ) corrected to $65^{\circ} \mathrm{C}$, which was the temperature used in their biomass dry matter determinations. Other reported values that are assumed were as provided by the analytical laboratory used

value is $0.534 \mathrm{~g} \mathrm{C} \mathrm{g}^{-1} \mathrm{dm}$ ) increases significantly with stand age, and, therefore, an age-adjusted carbon fraction should be applied to this component for stands aged 5 years or older. For stand less than 5-years-old, the $\mathrm{CF}=0.503$ (the value for inner bark). Consequently, the mean carbon fraction in radiata pine bark increases rapidly from approximately $0.50 \mathrm{~g} \mathrm{C} \mathrm{g} \mathrm{g}^{-1} \mathrm{dm}$ at stand age 4 years to 0.54 $\mathrm{g} \mathrm{C} \mathrm{g} \mathrm{g}^{-1} \mathrm{dm}$ by age 9 years to a maximum of $0.55 \mathrm{~g} \mathrm{C} \mathrm{g}^{-1} \mathrm{dm}$ by stand age 17 years and older. The revised carbon fractions are applied in the FCP as shown in Table 6 for actual biomass data.

Compared to the use of the default carbon fraction $\left(0.50 \mathrm{~g} \mathrm{C} \mathrm{g} \mathrm{g}^{-1} \mathrm{dm}\right)$, the revised carbon fractions increase the amount of aboveground live (AGL) carbon stored in 
Table 6 Carbon stock (t/ha) and sequestration (t/ha/year) estimates calculated by applying carbon fractions to radiata pine stand dry matter estimates in Madwick et al. (1977) and Webber and Madgwick (1983): (a) using a default carbon fraction of $0.50 \mathrm{~g} \mathrm{C} \mathrm{g}^{-1} \mathrm{dm}$ and (b) using tree component-specific carbon fractions for radiata pine in New Zealand

\begin{tabular}{|c|c|c|c|c|c|c|c|c|c|}
\hline a & \multicolumn{9}{|c|}{ Carbon stock estimates based on a carbon fraction of $0.50 \mathrm{~g} \mathrm{C} \mathrm{g}^{-1} \mathrm{dm}$} \\
\hline Stand age (years) & $\begin{array}{l}\text { Stem } \\
\text { wood }\end{array}$ & $\begin{array}{l}\text { Stem } \\
\text { bark }\end{array}$ & Branches & Needles & Cones & $\begin{array}{l}\text { AGL } \\
C\end{array}$ & \multicolumn{3}{|l|}{$\begin{array}{l}\text { AGL C } \\
\text { seq }\end{array}$} \\
\hline 2 & 0.09 & 0.03 & 0.06 & 0.18 & 0.00 & 0.36 & \multicolumn{3}{|l|}{0.36} \\
\hline 4 & 3.60 & 0.64 & 3.28 & 3.58 & 0.00 & 11.1 & \multicolumn{3}{|l|}{5.37} \\
\hline 6 & 11.3 & 1.46 & 7.49 & 5.78 & 0.00 & 26.0 & \multicolumn{3}{|l|}{7.48} \\
\hline 8 & 23.0 & 2.63 & 11.9 & 2.96 & 0.05 & 40.5 & \multicolumn{3}{|l|}{7.24} \\
\hline $9^{a}$ & 14.5 & 1.80 & 2.77 & 1.70 & 0.30 & 21.1 & & & \\
\hline 10 & 24.8 & 2.39 & 5.69 & 2.93 & 0.11 & 35.9 & \multicolumn{3}{|l|}{14.8} \\
\hline 17 & 107.4 & 10.9 & 11.0 & 5.41 & 2.51 & 137.3 & \multicolumn{3}{|l|}{14.5} \\
\hline 22 & 121.8 & 13.7 & 13.7 & 4.64 & 1.61 & 155.4 & \multicolumn{3}{|l|}{3.61} \\
\hline 29 & 168.7 & 16.2 & 12.8 & 4.10 & 4.65 & 206.4 & \multicolumn{3}{|l|}{7.29} \\
\hline $\begin{array}{l}\text { Residues following harvesting of stem } \\
\text { wood plus bark }\end{array}$ & 25.3 & 2.4 & 12.8 & 4.10 & 4.65 & 49.3 & & & \\
\hline $\begin{array}{l}\text { Residues following harvesting of stem } \\
\text { wood only }\end{array}$ & 25.3 & 16.2 & 12.8 & 4.10 & 4.65 & 63.0 & & & \\
\hline b & \multicolumn{9}{|c|}{ Carbon stock estimates based on the revised component-specific carbon fractions for radiata pine } \\
\hline Stand age (years) & $\begin{array}{l}\text { Stem } \\
\text { wood }\end{array}$ & $\begin{array}{l}\text { Stem } \\
\text { bark }\end{array}$ & Branches & Needles & Cones & $\begin{array}{l}\text { AGL } \\
C\end{array}$ & $\begin{array}{l}\text { AGL C } \\
\text { seq }\end{array}$ & $\begin{array}{l}\text { C sequestration } \\
\text { change }(\%)\end{array}$ & $\begin{array}{l}\text { C stock } \\
\text { change (\%) }\end{array}$ \\
\hline 2 & 0.08 & 0.03 & 0.06 & 0.19 & 0.00 & 0.36 & 0.36 & 1.6 & 1.6 \\
\hline 4 & 3.58 & 0.64 & 3.33 & 3.68 & 0.00 & 11.2 & 5.43 & 1.2 & 1.2 \\
\hline 6 & 11.3 & 1.5 & 7.6 & 5.94 & 0.00 & 26.3 & 7.55 & 1.0 & 1.1 \\
\hline 8 & 22.9 & 2.8 & 12.1 & 3.04 & 0.05 & 40.9 & 7.27 & 0.4 & 0.8 \\
\hline $9^{a}$ & 14.5 & 1.9 & 2.8 & 1.75 & 0.31 & 21.3 & & & 0.8 \\
\hline 10 & 24.7 & 2.6 & 5.8 & 3.01 & 0.11 & 36.2 & 14.9 & 0.6 & 0.7 \\
\hline 17 & 107.0 & 12.0 & 11.2 & 5.56 & 2.61 & 138.3 & 14.6 & 0.8 & 0.8 \\
\hline 22 & 121.3 & 15.0 & 13.9 & 4.76 & 1.67 & 156.6 & 3.66 & 1.2 & 0.8 \\
\hline 29 & 168.0 & 17.8 & 13.0 & 4.21 & 4.83 & 207.8 & 7.31 & 0.3 & 0.7 \\
\hline $\begin{array}{l}\text { Residues following harvesting of stem } \\
\text { wood plus bark }\end{array}$ & 25.2 & 2.7 & 13.0 & 4.21 & 4.83 & 49.9 & & & 1.3 \\
\hline $\begin{array}{l}\text { Residues following harvesting of stem } \\
\text { wood only }\end{array}$ & 25.2 & 17.8 & 13.0 & 4.21 & 4.83 & 65.0 & & & 3.2 \\
\hline
\end{tabular}

The resulting percentage changes in aboveground live (AGL) $\mathrm{C}$ stocks and $\mathrm{C}$ sequestration are shown (in part b) by stand age, as are the expected effects of harvesting the 29-year-old stand (Webber and Madgwick 1983), assuming stem wood plus bark extraction (85\%) or assuming stem wood only extraction (85\%), on carbon stocks of residues and stock changes (\%)

${ }^{a} \mathrm{C}$ sequestration of the 9-year-old stand was not calculated because this stand had been thinned, which explains why the AGL $\mathrm{C}$ stock decreased relative to the AGL C stock at age 8 years

mature stands by approximately $1 \%$. The amount of carbon retained on site as harvest residues during conventional stem-harvesting operations, which typically remove $85 \%$ of the stem wood plus bark, increased by $1.3 \%$, unless harvested stems were entirely debarked at the stump in which case the amount of carbon retained on site as harvest residues increased by $3.2 \%$, when using the revised instead of the default carbon fractions (Table 6). Component carbon fractions are similar in Douglas-fir and radiata pine biomass components. It was, therefore, assumed that the component- and age-specific (for stem bark) carbon fractions for radiata pine are applicable to other coniferous species in New Zealand's planted forest estate.

\section{Conclusions}

Robust carbon fractions have been developed for biomass components of radiata pine in New Zealand. Analysis shows that the default carbon fraction $\left(0.50 \mathrm{~g} \mathrm{C}^{-1} \mathrm{dm}\right)$ used in the FCP model underestimates carbon stocks in New Zealand's planted forests by approximately 1\%. Applying the revised carbon fractions derived above from 
specific biomass components of commonly planted species in New Zealand in the FCP model will improve the accuracy of carbon stock estimates for planted forest. Moreover, operational information on in-forest debarking activities that provide estimates of the percentage of stem bark mechanically removed during harvesting operations will further improve estimates of removals associated with harvesting, and additional work is required to achieve this.

\begin{abstract}
Abbreviations
AGL: Aboveground live biomass; C: Carbon; CF: Carbon fraction;

$\mathrm{CF}_{104}$ : Carbon of samples dried to constant weight at $104^{\circ} \mathrm{C} ; \mathrm{CF}_{70}$ : Carbon fraction of samples dried to constant weight at $70^{\circ} \mathrm{C}$; FCP: Forest Carbon Predictor; IPCC: Intergovernmental Panel on Climate Change; NI: North Island of New Zealand; SI: South Island of New Zealand; UNFCCC: United Nations Framework Convention on Climate Change
\end{abstract}

\section{Acknowledgements}

Funding to facilitate the preparation of this manuscript was provided by the New Zealand Ministry for the Environment under Head Agreement 20059, Statement of Work 21078. Tree component biomass samples included in this analysis were acquired from biomass studies that had been undertaken using funding from a range of sources, including Growing Confidence in Forestry's Future GCFF research programme funded by MBIE, SLMACC projects funded by Ministry of Primary Industries, and an Underpinning Research Contract funded by Ministry for the Environment. The authors acknowledge the contribution of Mark Kimberley for statistical assistance.

\section{Funding}

Funding to facilitate data analysis and publication of this manuscript was provided by the Ministry for the Environment under Head Agreement Reference 20059, Statement of Work 21078.

\section{Availability of data and materials}

Please contact author for data requests.

\section{Authors' contributions}

PNB developed the concept for this manuscript and was the primary author. LGG contributed towards data collation from decay studies and contributed to writing the paper. Both authors have read and approved the final version of the manuscript.

\section{Ethics approval and consent to participate}

Not applicable

\section{Consent for publication}

Not applicable

\section{Competing interests}

The authors declare that they have no competing interests.

\section{Publisher's Note}

Springer Nature remains neutral with regard to jurisdictional claims in published maps and institutional affiliations.

Received: 21 February 2018 Accepted: 13 November 2018

Published online: 07 December 2018

\section{References}

Balboa-Murias, M. A., Rodriguez-Soalleiro, R., Merino, A., \& Alvarez-Gonzalez, J. G. (2006). Temporal variations and distribution of carbon stocks in aboveground biomass of radiata pine and maritime pine pure stands under different silvicultural alternatives. Forest Ecology and Management, 237, 29-38.

Beets, P. N., Kimberley, M. O., Paul, T. S. H., \& Garrett, L. G. (2011). Forest carbon monitoring system - forest carbon model validation study for Pinus radiata. New Zealand Journal of Forestry Science, 41, 177-189.
Beets, P. N., \& Madgwick, H. A. I. (1988). Above-ground dry matter and nutrient content of Pinus radiata as affected by lupin, fertiliser, thinning, and stand age. New Zealand Journal of Forestry Science, 18, 43-64.

Beets, P. N., \& Pollock, D. S. (1987). Accumulation and partitioning of dry matter in Pinus radiata as related to stand age and thinning. New Zealand Journal of Forestry Science, 17, 246-271.

Bert, D., \& Danjon, F. (2006). Carbon concentration variations in the roots, stem and crown of mature Pinus pinaster (Ait.). Forest Ecology and Management, 222, 279-295.

De Aza, C. H., Turrion, M. B., Pando, V., \& Bravo, F. (2011). Carbon in heartwood, sapwood and bark along the stem profile in three Mediterranean Pinus species. Annals of Forest Science, 68, 1067-1076.

Garrett, L. G., Kimberley, M. O., Oliver, G. R., Pearce, S. H., \& Beets, P. N. (2012). Decomposition of coarse woody roots and branches in managed Pinus radiata plantations in New Zealand - a time series approach. Forest Ecology and Management, 269, 116-123.

Garrett, L. G., Kimberley, M. O., Oliver, G. R., Pearce, S. H., \& Paul, T. S. H. (2010). Decomposition of woody debris in managed Pinus radiata plantations in New Zealand. Forest Ecology and Management, 260, 1389-1398.

Garrett, L. G., Oliver, G. R., Pearce, S. H., \& Davis, M. R. (2008). Decomposition of Pinus radiata coarse woody debris in New Zealand. Forest Ecology and Management, 255, 3839-3384.

IPCC. (2006). 2006 IPCC Guidelines for National Greenhouse Gas Inventories. Prepared by the National Greenhouse Gas Inventories Programme and H. S. Eggleston, L. Buendia, K. Miwa, T. Ngara, \& K. Tanabe (Eds.). Kanagawa: Institute for Global Environmental Strategies.

Losi, C. J., Siccama, T. G., Condit, R., \& Morales, J. E. (2003). Analysis of alternative methods for estimating carbon stock in young tropical plantations. Forest Ecology and Management, 184, 355-368.

Madwick, H. A. I., Jackson, D. S., \& Knight, P. J. (1977). Above-ground dry matter, energy, and nutrient content of trees in an age series of Pinus radiata plantations. New Zealand Journal of Forestry Science, 7, 445-468.

Matthews, G. (1993). The carbon content of trees. [Technical Paper 4]. Edinburgh: Forestry Commission.

Matthews, S. (2010). Effect of drying temperature on fuel moisture content measurements. International Journal of Wildland Fire, 19, 800-802.

NEFD. (2016). National Exotic Forest Description as at 1 April 2016. Wellington: Ministry for Primary Industries

Oliver, G. R., Beets, P. N., Pearce, S. H., Graham, J. D., \& Garrett, L. G. (2011). Carbon accumulation in two Pinus radiata stands in the North Island of New Zealand. New Zealand Journal of Forestry Science, 41, 71-86.

Samuelsson, R., Nilsson, C., \& Burvall, J. (2006). Sampling and GC-MS as a method for analysis of volatile organic compounds (VOC) emitted during oven drying of biomass materials. Biomass and Bioenergy, 30, 923-928.

SAS Institute Inc. (2011). Base SAS ${ }^{\oplus} 9.3$ Procedures Guide. Cary, NC: SAS Institute Inc.

Thomas, S. C., \& Martin, A. R. (2012). Carbon content of tree tissues: a synthesis. Forests, 3, 332-352.

Uprichard, J. M., \& Lloyd, J. A. (1980). Influence of tree age on the chemical composition of radiata pine. New Zealand Journal of Forestry Science, 10, 551-557.

Webber, B., \& Madgwick, H. A. I. (1983). Biomass and nutrient content of a 29-yearold Pinus radiata stand. New Zealand Journal of Forestry Science, 7, 445-468.

\section{Submit your manuscript to a SpringerOpen ${ }^{\circ}$ journal and benefit from:}

- Convenient online submission

- Rigorous peer review

- Open access: articles freely available online

High visibility within the field

- Retaining the copyright to your article

Submit your next manuscript at $>$ springeropen.com 